\title{
Seasonal and diel patterns in activity and habitat use by brook trout (Salvelinus fontinalis) in a small Newfoundland lake
}

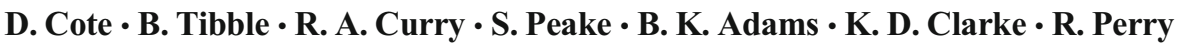

Received: 8 January 2019 /Accepted: 4 November 2019/Published online: 4 December 2019

(C) The Author(s) 2019

\begin{abstract}
Despite the challenges winter poses to salmonids inhabiting temperate and northern environments, there are relatively few studies that evaluate the factors that influence activity and habitat use during this season, particularly for lake environments that are ice-covered. This study examines brook trout depth distribution and movement (activity and range) in relation to temperature, light, and time of day across a 17-month period in a small lake in Newfoundland, Canada. Brook trout maintained elevated diurnal activity patterns throughout the year, despite seasonal changes in temperature, shifts in depth use, and prolonged, ice-induced darkness. Despite the tendency for relatively lower activity at night, brook
\end{abstract}

Electronic supplementary material The online version of this article (https://doi.org/10.1007/s10641-019-00931-1) contains supplementary material, which is available to authorized users.

D. Cote $(\varangle) \cdot$ K. D. Clarke

Fisheries and Oceans Canada, 80 East White Hills Rd, St. John's, NL A1C 5X1, Canada

e-mail: dave.j.cote@gmail.com

B. Tibble

Tulloch Environmental, a division of Tulloch Engineering Inc., Unit L, 1942 Regent St, Sudbury, ON P3E5V5, Canada

R. A. Curry $\cdot$ S. Peake

Canadian Rivers Institute, Biology Department, and Faculty of Forestry and Environmental Management, University of New Brunswick, Fredericton, NB E3B 5A3, Canada

B. K. Adams · R. Perry

Department of Fisheries and Land Resources, Wildlife Division, Government of Newfoundland and Labrador, 192 Wheelers Rd, Corner Brook, NL A2H 7S1, Canada trout remained active nocturnally, inferring a shift in foraging modes rather than a cessation of feeding. Winter movement velocities and ranges were less than other seasons but they occupied littoral areas that overlapped extensively with spring and fall core ranges. In contrast, summer core ranges of brook trout were principally comprised of areas with cooler water in the deep portion of the lake. As water temperature increased, daytime movement velocities increased in a log-linear fashion, whereas modeled nighttime movement velocity relationships with temperature were curvilinear and included the lowest movement velocities at $2-3{ }^{\circ} \mathrm{C}$ and the highest at the extremes of the occupied temperature range. The ability of brook trout to maintain diurnal activity patterns throughout a wide spectrum of environmental conditions suggests a strong behavioral and physiological capacity to adapt to their seasonally variable environment.

Keywords Brook trout - Winter-Activity - Telemetry Diel $\cdot$ Movement velocity $\cdot$ Home range

\section{Introduction}

In temperate and Arctic regions, winter imposes challenging environmental conditions that can lead to metabolic and food limitations, changing predation risks, and environmental volatility (Brown et al. 2011; McMeans et al. 2015). Animals adapt to these environmental conditions through a variety of morphological (Prestrud 1991), physiological (Goddard et al. 1992), 
and behavioral responses that include migration/habitat selection (Angiletta et al. 2002; Linnansaari and Cunjak 2013; Goyer et al. 2014) and hibernation/torpor (Curry et al. 2005). Fish in these environments face an additional set of challenges due to dynamic ice conditions, which can rapidly modify habitat suitability (Linnansaari and Cunjak 2010). In small streams and rivers, this habitat instability, combined with decreased food availability and lowered metabolic rates, can reduce fish survival (Sweka et al. 2004; Utz and Hartman 2006). Snow accumulation on ice and low temperatures in lake environments has also led to recruitment failures in some salmonids (Borgstrøm and Museth 2005). Unfortunately, the vast majority of studies of aquatic organisms in northern regions are conducted during open water seasons when they are more accessible to researchers (Huusko et al. 2007) and therefore, there is limited information on the overwintering behaviors of most north temperate and northern fish species (Mulder et al. 2018a).

Brook trout Salvelinus fontinalis, a widespread, cold water species endemic to northeastern North America (Scott and Crossman 1973), are a popular species amongst anglers yet remain poorly studied in the winter period. For example, a considerable body of ecological research has been conducted on this species during the open water seasons (e.g., Magnan and Fitzgerald 1982; Tremblay and Magnan 1991; Bourke et al. 1996; Erkinaro and Gibson 1997; Mucha and Mackereth 2008) but few have targeted brook trout under the ice. Those studies done in winter have been largely focused on fluvial environments (but see Cavalli et al. 1997; Spares et al. 2014) and have found that brook trout overwintering in streams were largely inactive, aggregated in deep pools or near ground water seeps, and only moved sporadically in response to destabilized ice conditions (Huusko et al. 2007). Unlike open water periods, fluvial brook trout have been reported to be nocturnal in winter (Meyer and Gregory 2000), which may be a response that minimizes predation risk during a time when their metabolism is low (Huusko et al. 2007). Nevertheless, lake environments can also serve as important habitats for brook trout (e.g., Cote et al. 2011). Lakes can favor growth conditions (Jardine et al. 2005) as well as provide refugia likely related to greater environmental stability during winter extremes (Curry et al. 2006; Pépino et al. 2017). However, lakes can experience periods of anoxic conditions associated with vertical temperature structuring and mixing throughout the winter (Wetzel 2001; Dillon et al. 2003; Guzzo and Blanchfield 2017).
Brook trout living in lake environments, therefore, may not exhibit the same behavioral adaptations such as restricted movements or nocturnalism as those used in fluvial habitats and may adopt other strategies to avoid anoxic conditions or to forage under ice in low light conditions (e.g., Snucins and Gunn 1995). Unfortunately, little knowledge exists of the winter behavior and habitat use of brook trout in lakes beyond what is based on under-ice catches (Lackey 1969; Lackey 1970; Bourke et al. 1996; Fraser and Bernatchez 2008) or intermittent tracking (Curry et al. 2006; Mucha and Mackereth 2008). The lack of winter behavior information leaves important knowledge gaps related to the presence of diel activity patterns, bioenergetics, mortality, and resource partitioning processes that could be altered with our changing climate (e.g., Chu et al. 2005; Jeppesen et al. 2010).

Herein, we used acoustic telemetry and a fixed receiver grid to track the seasonal patterns of movement and occupied habitats (depth, temperature) of lake-resident, adult brook trout for a continuous period of 17 months. We hypothesized that increased habitat stability in lake environments would enable continuous activity of brook trout during winter periods as opposed to the sporadic activity previously documented in fluvial habitats. We also predicted that diel fish activity patterns would be less pronounced when the lake was icecovered because of reduced light levels and a relatively stable thermal regime. Similarly, we predicted that depth use restrictions would also relax during the winter period because the water column had a smaller thermal gradient as opposed to observations made in summer when thermoregulation can be important (Bertolo et al. 2011; Goyer et al. 2014).

\section{Methods}

The study was conducted in Little Bear Cave Pond (LBCP), a 235-ha dimictic lake in the upper reaches of the Indian Bay watershed in central Newfoundland, Canada (Fig. 1). The lake has a maximum depth of $12 \mathrm{~m}$ and a mean depth of $4.1 \mathrm{~m}$. Ice conditions vary but typically ice forms in December and extends into April. The lake supports a fish community dominated by brook trout and anadromous and landlocked Atlantic salmon (Salmo salar), as well as populations of rainbow smelt (Osmerus mordax), three-spined stickleback (Gasterosteus aculeatus), American eel (Anguilla rostrata), and banded killifish (Fundulus diaphanus). Based on genetic and 


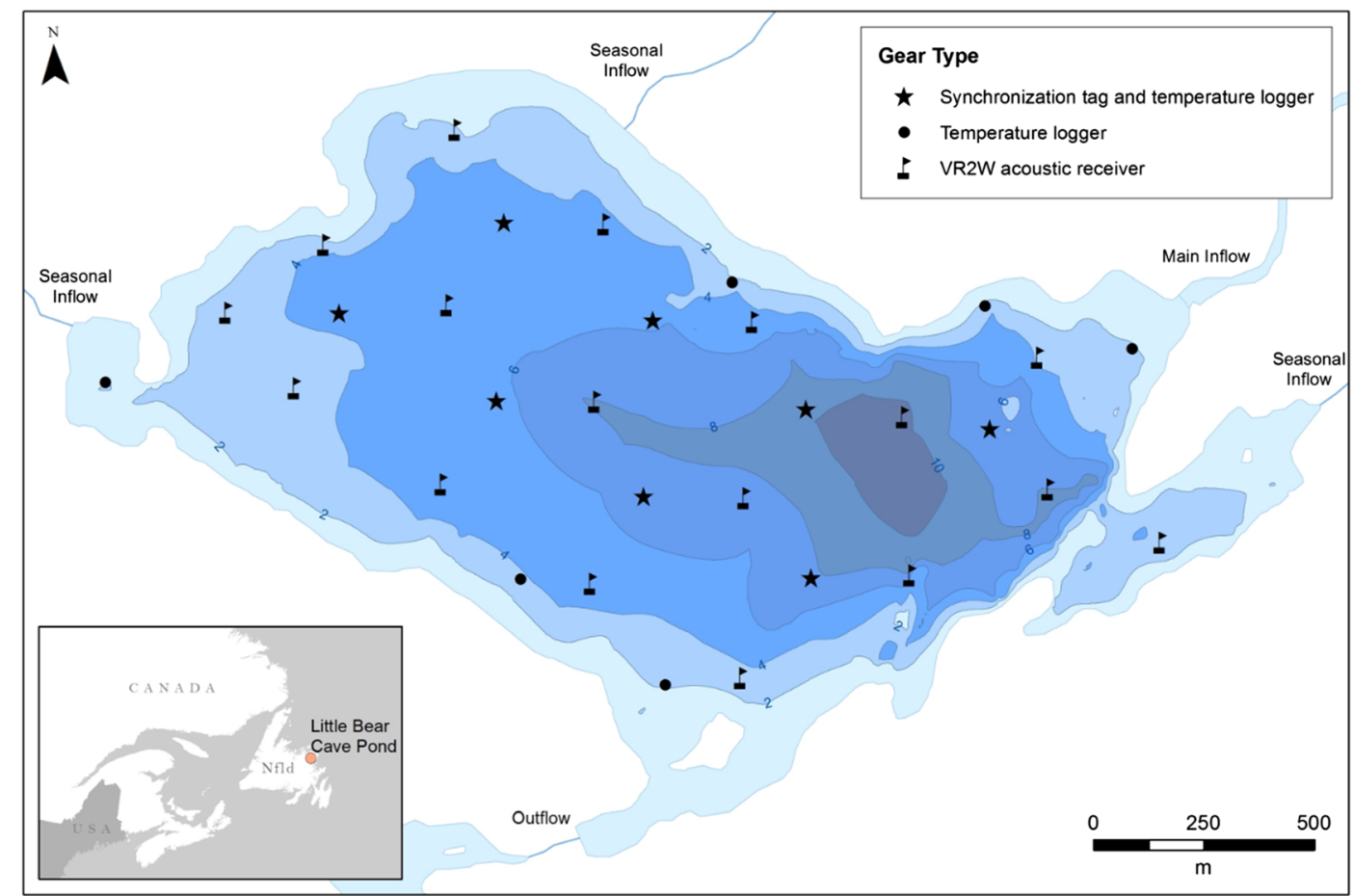

Fig. 1 Bathymetry of Little Bear Cave Pond and the acoustic receiver grid used for monitoring movements of brook trout tagged with acoustic transmitters in (September 2008 to February 2010).

mark-recapture data, lake populations of brook trout in Indian Bay watershed are thought to be reproductively isolated (Adams and Hutchings 2003).

Fish sampling

Brook trout were collected between September 10 and October 22, 2008, using trap nets and angling at locations throughout the lake (Table 1). Twenty-two fish greater than $250 \mathrm{~g}$ were retained and surgically implanted with Vemco model V9TP-2L coded acoustic tags (47 mm [length], $9 \mathrm{~mm}$ [diameter], $7.5 \mathrm{~g}$ in air) using the methods described by Anderson et al. (1997) and Murchie and Smokorowski (2004).

Fish were anesthetized using a $40 \mathrm{mg} / \mathrm{L}$ clove oil bath, before being partially submerged in a surgery cradle where water was continuously pumped over their gills. Tags were inserted into the coelomic cavity of the pelvic girdle through a $25-\mathrm{mm}$ incision in the abdominal wall, and the incision was closed using a row of three to four monofilament sutures. Fish were also fitted with a coded floy tag posterior to the dorsal fin (Guy et al. 1996) before being placed in a $20-\mathrm{L}$ cooler containing clean, aerated lake water for $60-90 \mathrm{~min}$ to recover.
Temperature logger and synchronization tag sites are also indicated. Depths are represented in meters

Surgeries took less than 5 min to complete. Fish were released in the same general area from which they were collected. Acoustic tags transmitted a unique identification code, as well as recorded and transmitted the internal body temperature and pressure (depth) of tagged brook trout. Internal body temperature might be expected to lag changes to ambient temperatures (Pépino et al. 2015); however, this measure is more likely to reflect the conditions influencing fish physiology (e.g., metabolic rate). Acoustic tags were programmed to transmit data at random intervals within a range of $16-24 \mathrm{~min}$ in order to reduce signal collisions and to minimize memory overload of the receivers.

Two of the fish tagged in October 2008 were harvested by local anglers in the spring (T08) and winter (T15) fisheries. These tags were redeployed in two additional brook trout (T08b and T15b) in June 2009. Tagged brook trout ranged in size from 283 to $418 \mathrm{~mm}$ fork length (FL) (mean, $358 \pm 35 \mathrm{~mm} \mathrm{SD}$ ) and $278.1 \mathrm{~g}$ to $1008.1 \mathrm{~g}$ wet weight (WT) $(603.0 \pm 218.4 \mathrm{~g} \mathrm{SD})$. These fish were presumed to range in age between 4 and 6 years, based on standardized weight and age data from local brook trout populations (Indian Bay Ecosystem Corporation, Unpublished Data). 
Table 1 Brook trout tagged with acoustic tags in Little Bear Cave Pond, NL

\begin{tabular}{|c|c|c|c|c|c|c|c|c|}
\hline Fish & $\begin{array}{l}\text { Date } \\
\text { tagged }\end{array}$ & $\begin{array}{l}\text { Collection } \\
\text { gear }\end{array}$ & $\begin{array}{l}\text { Fork length } \\
(\mathrm{mm})\end{array}$ & $\begin{array}{l}\text { Wet weight } \\
(\mathrm{g})\end{array}$ & $\operatorname{Sex}^{\mathrm{a}}$ & $\begin{array}{l}\text { Last date } \\
\text { observed }\end{array}$ & Presumed fate & Detections \\
\hline T01 & 22 -Oct-08 & Angling & 338 & 613.5 & Male & 27-Feb-09 & Harvested/tag failure & 1484 \\
\hline T03 & 15-Sep-08 & Angling & 343 & 577.1 & Male & 04-Aug-09 & Left lake/tag failure & 7778 \\
\hline T04 & 12-Sep-08 & Angling & 415 & 934.3 & Female & 18-Aug-09 & Remained in lake except during spawning & 5413 \\
\hline T08 & 11-Sep-08 & Angling & 375 & 682.1 & Female & 22-May-09 & Harvested 22-May-09 & 2611 \\
\hline $\mathrm{T} 14$ & 18-Sep-08 & Trap net & 320 & 468.0 & Male & 02-Oct-09 & $\begin{array}{l}\text { Left lake before ice up, } 2008 \\
\text { Returned spring, } 2009 \\
\text { Moved downstream, Fall, } 2009\end{array}$ & 3758 \\
\hline $\mathrm{T} 15$ & 22-Oct-08 & Angling & 323 & 382.5 & Female & 02-Feb-09 & Harvested 2-Feb-09 & 1941 \\
\hline $\mathrm{T} 15 \mathrm{~b}$ & 13-Jun-09 & Trap net & 397 & 855.8 & Unknown & 12-Aug-09 & Harvested/tag failure & 473 \\
\hline T16 & 11-Sep-08 & Angling & 338 & 523.3 & Female & 18 -Feb-10 & Remained in lake & 8276 \\
\hline $\mathrm{T} 17$ & 28-Sep-08 & Angling & 399 & 816.3 & Male & 01-Feb-10 & Remained in lake & 4094 \\
\hline $\mathrm{T} 20$ & 10-Sep-08 & Trap net & 320 & 405.9 & Female & 19-Feb-10 & Remained in lake & 12051 \\
\hline
\end{tabular}

Only individuals that were used in the data analyses are shown $(N=10)$. Information related to the remaining tagged fish are provided in Supplement 1

${ }^{\text {a }}$ Sexes were determined visually using external secondary sex characteristics

Fish tracking and environmental monitoring

The positions of brook trout in the lake were monitored from September 2008 to February 2010 using an array of 17 Vemco VR2W, single-channel, hydroacoustic receivers (Fig. 1). Each receiver was placed $\sim 0.5 \mathrm{~m}$ above the bottom of the lake and secured to an $18-\mathrm{kg}$ anchor. Receivers were arranged in an equilateral triangle grid spaced $400 \mathrm{~m}$ apart, which accounted for the effective range of the acoustic tags $(80 \%$ signal reception; VEMCO 2008). Range testing confirmed this was an effective receiver spacing. Receivers were retrieved and redeployed at approximately 6-month intervals.

Eight stationary Vemco V16-H synchronization tags were placed throughout the lake (Fig. 1) to provide a continuous time reference to compensate for differences in the time drift of an individual receiver's internal clock. Hobo Pendant temperature data loggers (model UA-00108) were also deployed at 1-m depth intervals from $1 \mathrm{~m}$ above the bottom to $1 \mathrm{~m}$ below the surface to provide seasonal, lake temperature profiles (Fig. 1). Temperatures were also used to refine sound speed estimates and improve the accuracy of triangulations of tagged brook trout. Finally, Hobo Pendant temperature/light data loggers (model UA-002-64) were placed in the lake at $1 \mathrm{~m}$ below the surface.

Vertical profiles of water temperature, $\mathrm{pH}$, dissolved oxygen, and conductivity were collected once per season using an YSI model 556 MDS Data Sonde. Bathymetry maps were created from hydroacoustic data (BioSonics single beam DT-X echosounder).

\section{Data analysis}

Analyses focused on depth use and two activity metrics: movement velocity and range of movement. For all analyses, the data were grouped into seasons (Fig. 2). Spring (April 18-June 14, 2009) and fall (September 4-December 19, 2008, and August 19December 8, 2009) seasons were defined as the period when LBCP was isothermal, whereas winter (December 20, 2008-April 17, 2009, and December 8, 2009February 19, 2010) and summer (June 15-August 18, 2009) were periods of thermal stratification. The last winter season was truncated when the study ended. Also, winter season data was further subdivided into periods of open water or ice cover. Ice cover was defined as 24-h periods when no light was detected by light loggers deployed at $1 \mathrm{~m}$ depth.

Diel periods were subdivided into day, dusk, night, and dawn according to sunrise and sunset data (NRC 2009), with dawn and dusk encompassing a period equal to twice civil twilight (i.e., when the sun is within $6^{\circ}$ of the horizon).

Fish positions were estimated using hyperbolic positioning, when tag transmissions were detected on at least three acoustic receivers (Espinoza et al. 2011). Precision 

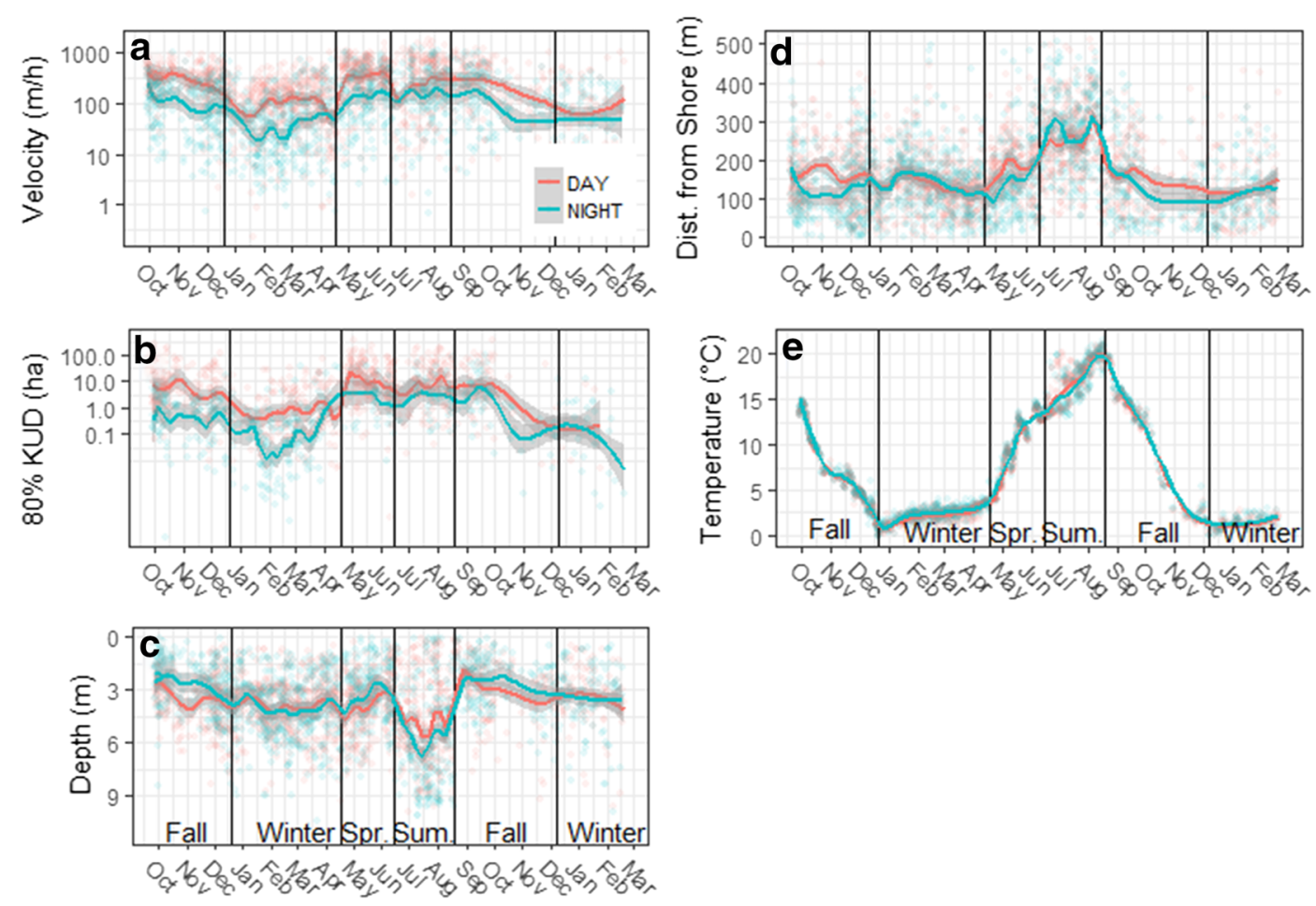

Fig. 2 Seasonal behavioral patterns both in the night and day for tagged brook trout in Little Bear Cave Pond between 2008 and 2009. a Activity rates, b Diel movement area based on $80 \%$ kernel densities, c Occupied depths, d Distance from shore, and e

of these positions was estimated using the synchronization tags and extrapolated to fish positions as horizontal positioning error (HPE) (Roy et al. 2014). Fish positions with HPE values greater than 20 were removed from the analysis. The remaining $80 \%$ of the data had estimated HPE values of $<12.5 \mathrm{~m}$.

Movement velocities of brook trout were estimated using the distance between consecutive positions divided by the difference in time between positions. Given that we did not account for possible deviations from the straightline path between consecutive positions, the calculated velocities were likely underestimates. However, error in successive points could also generate instances where movement velocity was overestimated. For example, a stationary fish might appear to be moving due to error in successive position estimates. These overestimates were considered negligible ( $\sim 1.25 \mathrm{~m} / \mathrm{min})$, given the relatively long transmission interval used in this study.

Serial correlation is an analytical challenge of telemetry data because the technology permits repeated measurements of individuals at high temporal resolution. Therefore, it is not unusual that these datasets lack
Occupied temperature. Dashed vertical lines represent season transitions. Data points reflect daily average values for individual fish for all data of suitable precision. LOESS smoothers $(\operatorname{span}=0.1$, with standard errors) of these data are overlaid to illustrate trends

independence across successive data points (Dray et al. 2010). Analysis is further complicated in instances where data is collected at irregular intervals, as many sophisticated and increasingly accessible tools used to overcome serial correlation are designed for data collection at fixed intervals or are not suitable for analyses within a mixed model framework (e.g., momentuhmm package in R; McClintock and Michelot 2018). In this case, we dealt with serial correlation by thinning the data to a single randomly selected record within successive 6-h time blocks. Examination of residuals from the best velocity models confirmed that a 6 -h interval was sufficient to limit serial correlation.

We then assessed whether diel period, water temperature, season, and ice cover influenced movement velocities of tagged individuals within a mixed effect generalized additive model (gam in mgcv package in $\mathrm{R}$ ).

The full model was formulated as follows:

Velocity $\sim \mathrm{s}($ Hour of Day $)+\mathrm{s}($ Temperature $)+$ Season $+1 \mid$ Fish ID

where Velocity is in meters per hour. Predictor variables included smoothed variables of Hour of Day and 
Temperature $\left({ }^{\circ} \mathrm{C}\right)$ using cyclic and cubic regression splines, respectively, whereas Season was included as a categorical variable. A random intercept for Fish ID was applied in the gam model using a random effect smoother. Additional variants of this model were included to assess specific questions of interest. First, to determine the influence of ice presence on fish velocity, we reran the season models that distinguished winter conditions with and without ice. If model fit improved, we could conclude that the presence of ice had altered fish activity. To address the question of whether diel activity patterns change by season or remain static, we ran a second set of models with and without season-specific smoothers for hour of day. Finally, we attempted to assess whether diel period mediated movement velocity responses to water temperature by applying day- and night-specific smoothers to the best model (assuming it included Hour of Day and Temperature).

Competing models were assessed using the Akaike information criterion (AIC) using the recommendations of Burnham and Anderson (2004) in which models with $\triangle \mathrm{AIC}$ scores of less than 2 have substantial support.

Range of brook trout movement was also assessed across temporal periods. We used $80 \%$ kernel density estimates with least square cross-validation smoothers (adehabitat package for R; Calenge 2006) on day and night periods with a minimum of 10 positions (Börger et al. 2006). The kernel densities were then analyzed using a generalized linear mixed effects model (lme4 package in R) with a gamma (log link) error structure. The full model examined was:

\section{Range $\sim$ Diel Period $\times$ Season $+1 \mid$ Fish ID}

where range represents the area in ha of the $80 \%$ kernel area and diel period was restricted to Day or Night. As before, potential effects of ice cover on the range of fish was assessed by replacing Season with a variant that split winter periods into open water and ice covered. Finally, a random intercept was included for Fish ID. Model fit was assessed with $\triangle \mathrm{AIC}$ scores. Tukey post hoc tests were conducted on the best model using the emmeans package in R. Since tagged fish collectively used much of the lake habitat across entire seasons, core areas were used for seasonal comparisons. Specifically, $50 \%$ kernel densities and least squares cross-validation smoothing were assessed against a null model with a generalized linear mixed effects model (random intercept for Fish ID and a gamma (log link) error structure) and using $\triangle \mathrm{AIC}$ scores.

Depth use was evaluated using data thinned to 6-h intervals and included models of similar structure, predictor variables, and variants as those used for movement velocity. There was an exception wherein temperature was not included in depth models due to the transmitters alternating between depth and temperature transmissions. Therefore, no concurrent temperature and depth data were available.

The following full model and subsets were evaluated using $\triangle \mathrm{AIC}$ criteria:

Depth $\sim$ S(Hour of Day $)+$ Season $+1 \mid$ Fish ID

where Depth represented the depth of the fish in the water column in meters. As before, Season was a categorical variable that could be replaced by a variant that divided up Winter into open water and ice-covered periods. Hour of Day (with a cyclical smoother) was specified with a common smoother to all seasons or a season-specific smoother. Once again, a random intercept was defined for each tagged fish.

\section{Results}

Six (T03, T04, T14, T16, T17, and T20) of 22 tagged brook trout remained in the lake for the duration of the study. Each fish was tracked for a mean of 440 days (range, 310-509 days; Table 1). An additional 4 brook trout $(\mathrm{T} 01, \mathrm{~T} 08, \mathrm{~T} 15$, and $\mathrm{T} 15 \mathrm{~b})$ remained in the lake for two seasons (65-236 days; Table 1) and were included in the analyses of the corresponding periods. Therefore, data analyses for assessing movement patterns in LBCP was based on these 10 brook trout, which represented 36,397 positions of acceptable precision. There were insufficient data to include the other 12 tagged brook trout (Supplement 1); two tagged individuals ceased movement shortly after returning from the spawning grounds in November 2008 (presumed dead or to have expelled their tags); five trout did not return from the spawning grounds in 2008; and five returned after spawning in 2008 but emigrated from the lake before freeze-up. Two brook trout (T03 and T04) could not be located after August 4, 2009, and August 18, 2009, respectively. It is suspected that these brook trout were either harvested by local anglers or the tags malfunctioned. 
Seasonal dissolved oxygen (DO) concentrations stayed above 7.76 and only dropped below $9.0 \mathrm{mg} / \mathrm{L}$ once in mid-winter in the deepest part of the lake. Since DO never dropped below levels thought to influence brook trout habitat use (5 mg/L; Spoor 1990), this environmental variable was excluded from further analyses. Other statistics of brook trout habitat occurrence are provided in Table 2.

\section{Movement velocity}

The best model for predicting brook trout movement velocities (adjusted $R^{2}=0.23$ ), using $\triangle$ AIC model selection criteria included Season, Fish Temperature, and Season-specific Hour of Day smoothers (Table 3). Furthermore, this model included the season variant that accounted for the presence or absence of ice as it marginally improved performance when compared with the model with no ice cover specification.

Movement velocity fluctuated over the year, slowly declining as waters cooled in the fall, reaching their lowest point during winter (Fig. 2). Brook trout velocities quickly increased to their highest levels at the onset of spring then fell to an intermediate level as temperatures warmed progressively throughout the summer. The cycle began to repeat itself the following fall, as velocities progressively declined below witnessed summer levels then subsequently returning to their lowest levels in the last winter of the study period.

Additionally, among all seasons, model results showed elevated movement velocities for brook trout during day and dusk periods when compared with those during night and dawn velocities (Fig. 3). While specifying season-specific smoothers accounted for the
Table 3 Best models for movement velocity of brook trout $(n=$ 10) in Little Bear Cave Pond, NL

\begin{tabular}{lll}
\hline Model & df & $\Delta$ AIC \\
\hline HoD* by ice season + ice season + temp* & 38.9 & 0 \\
HoD* by season + season + temp* & 33.5 & 4.3 \\
HoD* by season + season & 34.9 & 84.6 \\
HoD* + ice season + temp* & 18.4 & 86.4 \\
HoD* + season + temp* & 17.2 & 88.6 \\
HoD* by ice season + ice season & 39.9 & 89.7 \\
HoD* + temp* & 15.1 & 155.4 \\
HoD* + season & 17.3 & 177.3 \\
HoD* + ice season & 18.3 & 179.0 \\
Ice Season + temp* & 12.7 & 492.7 \\
Season + temp* & 11.5 & 493.7 \\
HoD* by season & 32.3 & 515.7 \\
Temp* & 8.9 & 553.4 \\
Season & 5.0 & 565.6 \\
Ice Season & 6.0 & 567.4 \\
HoD* & 17.0 & 585.8 \\
Null Model & 9.5 & 878.0 \\
\hline
\end{tabular}

Model components included HoD (hour of day), season with (ice season) and without ice (season) differentiation, and temp (temperature). The lowest $\triangle \mathrm{AIC}$ score indicates best model

*Denotes smoothed terms

changes in diel patterns attributable to changing day length, we still witnessed diel patterns that differed in magnitude among seasons. For example, model estimates for spring indicate that brook trout movement velocity climbed from a low of less than $100 \mathrm{~m} / \mathrm{h}$ at 04:00 to a peak that exceeded $500 \mathrm{~m} / \mathrm{h}$ at 09:00 (Fig. 3). In comparison, the changes in winter movement

Table 2 Mean daily values (unless otherwise noted) of brook trout activity and habitat use in Little Bear Cave Pond, NL

\begin{tabular}{llllll}
\hline & Fall & Winter open & Winter ice & Spring & Summer \\
\hline Seasonal core range (50\% kernel, ha) & $37.5(16.9-60.1)$ & $28.7(16.0-44.4)$ & $26.8(13.8-43.4)$ & $47.3(21.3-70.7)$ & $39.0(27.5-57.8)$ \\
Diurnal range (80\% kernel, ha) & $15.8(7.4-26.3)$ & $3.7(1.3-7.5)$ & $4.2(0.8-8.8)$ & $25.4(6.8-43.8)$ & $23.7(9.9-43.5)$ \\
Nocturnal range $(80 \%$ kernel, ha) & $2.7(0.6-6.7)$ & $2.8(0.1-5.4)$ & $0.9(0.1-2.6)$ & $7.2(1.5-18.5)$ & $16.2(2.6-39.7)$ \\
Movement velocity (m/h) & $271(60-541)$ & $131(15-298)$ & $128(16-291)$ & $363(112-641)$ & $387(59-776)$ \\
Depth $(\mathrm{m})$ & $2.9(1.2-5.0)$ & $3.9(1.8-6.1)$ & $3.5(1.3-5.6)$ & $3.6(1.6-5.9)$ & $5.0(1.7-7.7)$ \\
Distance above bottom (m) & $1.1(0.1-2.6)$ & $0.5(0.1-1.2)$ & $0.5(0.1-1.2)$ & $0.9(0.1-1.9)$ & $2.0(1.0-3.3)$ \\
Distance from shore $(\mathrm{m})$ & $147(48-256)$ & $134(45-221)$ & $132(45-226)$ & $159(62-249)$ & $265(149-378)$ \\
Temperature occupied $\left({ }^{\circ} \mathrm{C}\right)$ & $8.7(2.2-15.1)$ & $2.3(1.0-3.5)$ & $1.8(0.8-2.7)$ & $9.5(4.2-13.3)$ & $17.1(13.7-19.9)$ \\
\hline
\end{tabular}

Values displayed as the mean, and 10th and 90th percentiles. In seasons sampled more than 1 year (fall and winter), data are aggregated across years 


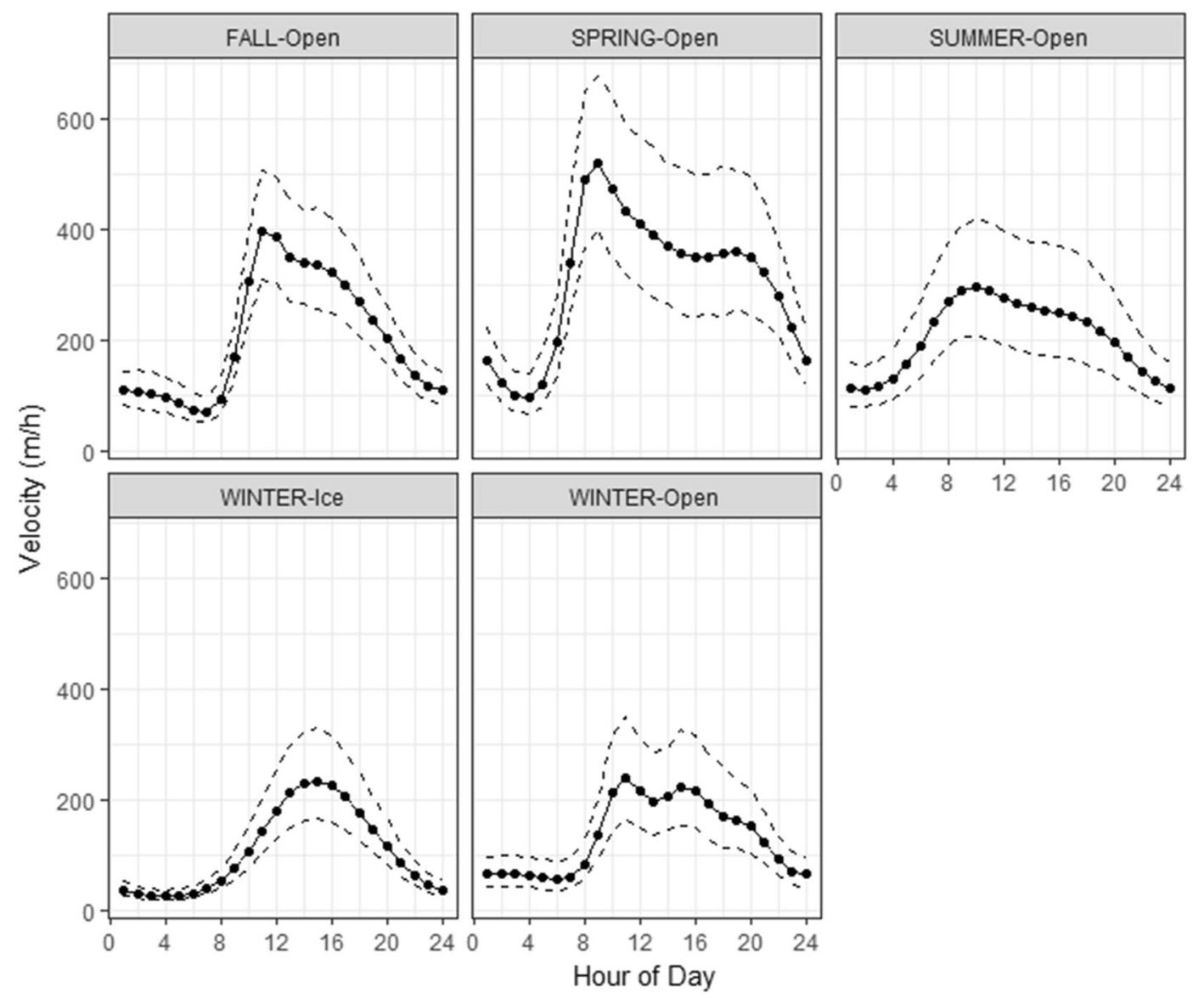

Fig. 3 Best model predictions for season-specific activity of brook trout in LBCP through the diel cycle. Solid lines represent a GAM smoother fit to the data and dashed lines reflect $95 \%$ confidence intervals of the model predictions

velocity estimates were diminished and only ranged from a minimum of less than $100 \mathrm{~m} / \mathrm{h}$ in the early morning to high just exceeding $200 \mathrm{~m} / \mathrm{h}$ by mid-day. The model that accounted for the presence of ice cover did improve the model; however, the difference in diel patterns between ice-covered and open water periods was subtle (Fig. 3).

Our best single variable model included Temperature (Table 3) and as temperature fluctuated during different periods of the day, it prompted us to consider that the influence of temperature on movement velocity might differ in active versus inactive diel periods. Consequently, we modified the best movement velocity model to include a diel period-specific smoother for temperature. The resulting model was improved, reducing the AIC score by 27 units. With diel period specified in the smoothed temperature term, model results did indeed show a different relationship between day and night. Daytime active periods showed a log-linear increase in velocity associated with temperature increases, whereas nocturnal movements first showed declining velocities as temperatures increased from 0 to $3{ }^{\circ} \mathrm{C}$ but then began to increase as temperatures continued to warm beyond 3 ${ }^{\circ} \mathrm{C}$ (Fig. 4). Interestingly, the highest modelled movement velocities during night occurred at the extremes of the temperature spectrum experienced by brook trout.

\section{Range of movement}

Diel brook trout range was best described by the full model that included terms for Season, Diel Period (Day or Night), and their interaction. Specifying ice cover also improved the model (Table 4). Post hoc tests show that diurnal ranges were significantly higher than nocturnal ones in every season $(p<0.001$; Fig. 5 and Table 2). Ranges for given diel periods did not differ across seasons however (all $p$ values $>0.61$ ), except for winter in which both ice-covered and open water 
Fig. 4 Best model predictions of movement velocity for brook trout in relation to temperature for day and night periods after controlling for factors associated with hour of day and season. The shape of the curves generically reflects the average responses to temperature for day and night; however, the $y$-intercept of these curves is arbitrarily specified to reflect the fall season and for midnight and noon during night and day periods, respectively. Dashed lines reflect $95 \%$ confidence intervals of the model predictions

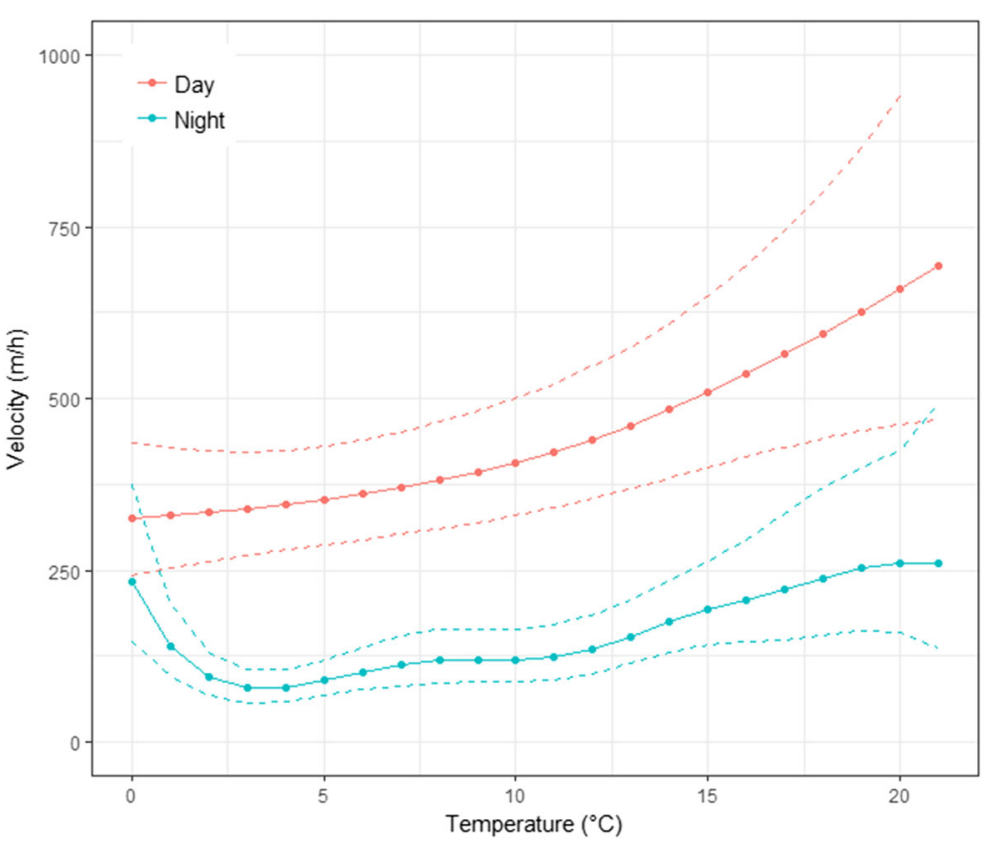

periods were significantly lower than the other seasons $(p<0.001)$. Modelled ranges were highest during spring (day, 22.4 ha; night, $5.7 \mathrm{ha}$ ), followed by summer (day, 21.4 ha; night, 5.4 ha), fall (day, 15.7 ha; night, 4.0 ha), and winter (open water day, 5.4; night, 1.4 and icecovered day, 2.5 ha; night, 0.7 ha). Model-predicted nighttime ranges were $25-28 \%$ of the daytime ranges in the same season. However, even the daytime range in winter was only a third of the nocturnal range during any other season.

Table 4 Best models for $80 \%$ kernel range areas of brook trout $(n$ $=10$ ) in Little Bear Cave Pond, NL

\begin{tabular}{lll}
\hline Model & df & $\Delta$ AIC \\
\hline Diel period x ice season & 12 & 0 \\
Diel period + ice season & 8 & 8.5 \\
Diel period x season & 10 & 18.8 \\
Diel period + season & 7 & 26.5 \\
Ice Season & 7 & 175.9 \\
Season & 6 & 185.9 \\
Diel period & 4 & 188.6 \\
Null model & 3 & 414.6
\end{tabular}

Model components included diel period (restricted to day and night), and season with (ice season) and without ice (season) differentiation. The lowest $\triangle \mathrm{AIC}$ score indicates best model
Seasonal core areas (50\% kernel density) of individuals overlapped across seasons, occurring primarily in the littoral zones of the lake (Fig. 6). Summer core areas were a notable exception however, occurring principally in the deepest basin (Fig. 6). Mean core area across all seasons ranged in size from 26.8 ha (winter ice) to 47 ha (spring) (Table 2). Season was not a good predictor of seasonal core area size as it did not improve the AIC score over the null model.

\section{Depth use}

Brook trout in LBCP spent most of their time near the bottom in shallow, nearshore waters, with over $70 \%$ of their recorded locations occurring in water less than $5 \mathrm{~m}$ in depth (Fig. 2; Table 2). Patterns of diel depth use, however, varied by season. The strongest depth use model (adjusted $R^{2}=0.235$ ) included variables for Hour of Day and Season, with ice cover specified (Table 5). Season-specific diel patterns were also an important inclusion in this model, as illustrated in Fig. 7, where diel depth use of brook trout in fall and spring were opposite to those in summer and winter. Differences between winter open water and ice-covered conditions were more subtle and this is supported by the small improvements (3.9) in $\triangle \mathrm{AIC}$ scores when we included ice cover in the season category. While depth use was quite variable (Fig. 2), brook trout tended to stay in 
Fig. 5 Brook trout $80 \%$ kernel density range across seasons and ice cover conditions, and day/ night periods in Little Bear Cave Pond from fall 2008 to winter 2009. Horizontal lines represent median catch rates, boxes represent the middle quartiles, and whiskers represent 1.5 times the interquartile range. Data beyond the whiskers are represented as individual data points

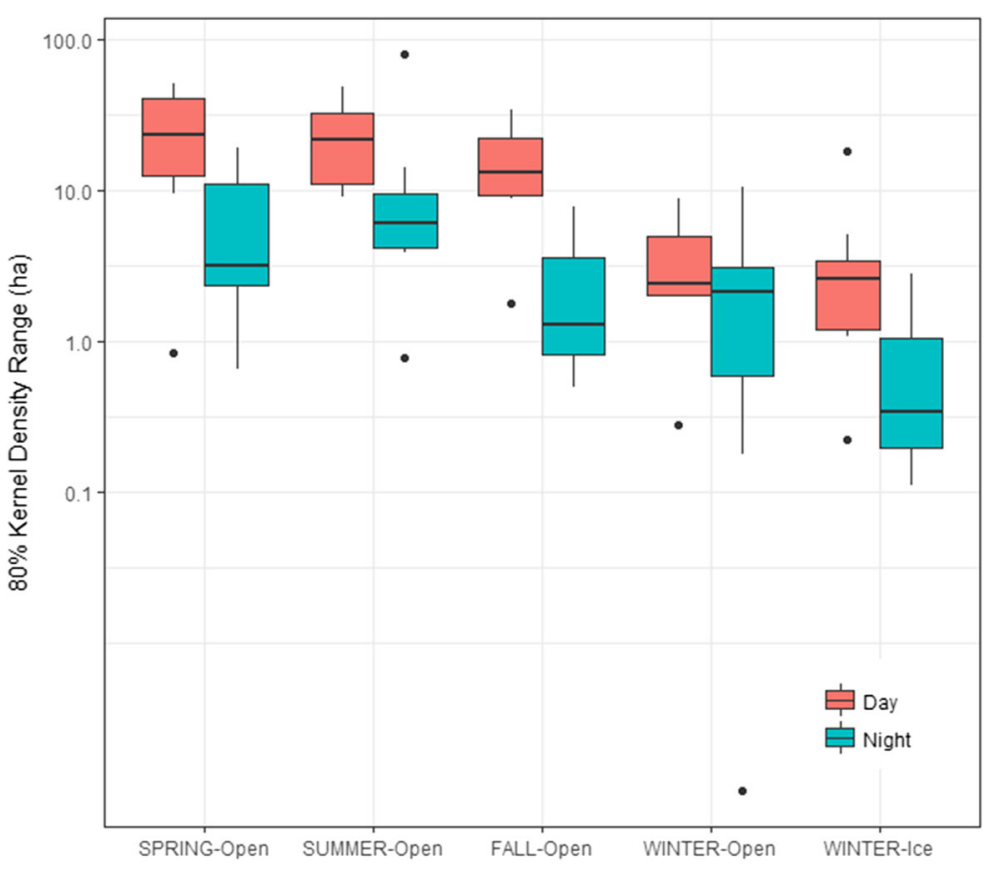

waters shallower than $6 \mathrm{~m}$, except during summer when they frequently occupied deeper and relatively cool habitats and were largely absent from warm surface waters (Figs. 2 and 8). Despite the divergent patterns observed across seasons, model results indicate the brook trout tended to occupy depths of $\sim 3-5 \mathrm{~m}$ during
Fig. 6 Core areas (50\% kernel home range) for Little Bear Cave Pond brook trout in fall and winter of 2008 and 2009 and spring and summer of 2009. Colors represent different individuals
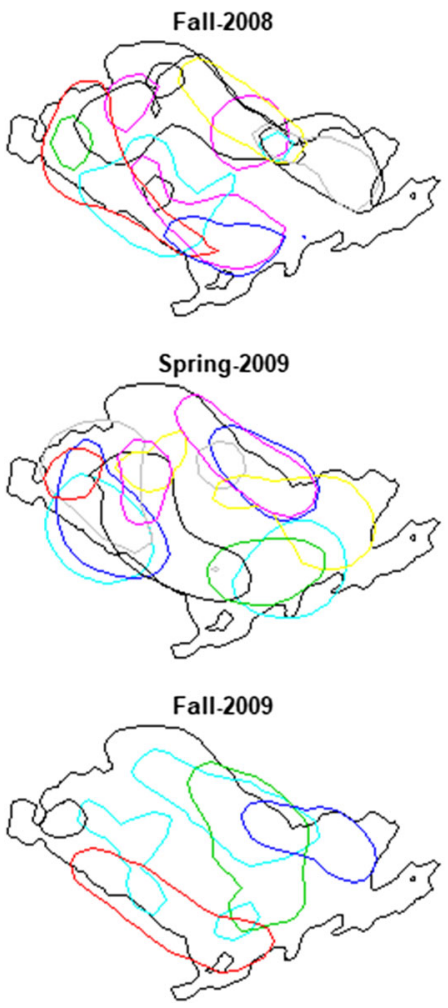
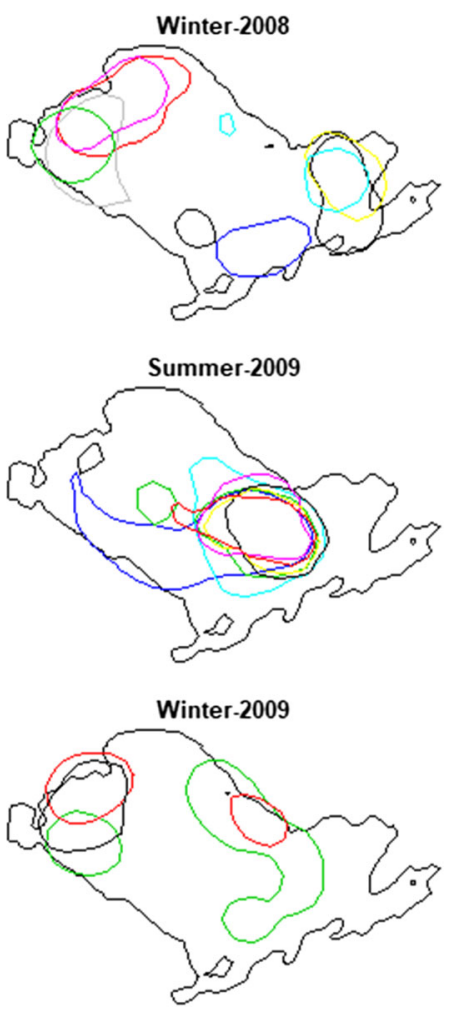
Table 5 Best models for depth use of brook trout $(n=10)$ in Little Bear Cave Pond, NL

\begin{tabular}{lll}
\hline Model & df & $\Delta$ AIC \\
\hline HoD* by ice season + ice season & 36.1 & 0 \\
HoD* by season + season & 33.2 & 3.9 \\
HoD* + ice season & 20.5 & 391.5 \\
HoD* + season & 19.5 & 393.0 \\
Ice season & 14.9 & 411.5 \\
Season & 13.9 & 413.0 \\
HoD* + season & 27.7 & 753.0 \\
HoD* & 15.6 & 1109.4 \\
Null model & 9.9 & 1126.4 \\
\hline
\end{tabular}

Model components included HoD (hour of day), and season with (ice season) and without ice (season) differentiation. The Lowest $\triangle \mathrm{AIC}$ score indicates best model

*Denotes smoothed terms their active diurnal periods, regardless of season. What differed was where brook trout spent nights, which was in relatively deep water far from shore in summer and in shallow water close to shore during spring and fall (Fig. 2). Diel patterns in depth use were much less pronounced in winter time (Figs. 2 and 7).

\section{Discussion}

Brook trout display remarkable habitat plasticity; existing in freshwater fluvial, lacustrine, and marine habitats (Jardine et al. 2005; Spares et al. 2014). Within waterbodies, brook trout can also modify their activity patterns or habitat use in accordance with environmental conditions such as predation risk, food availability, or

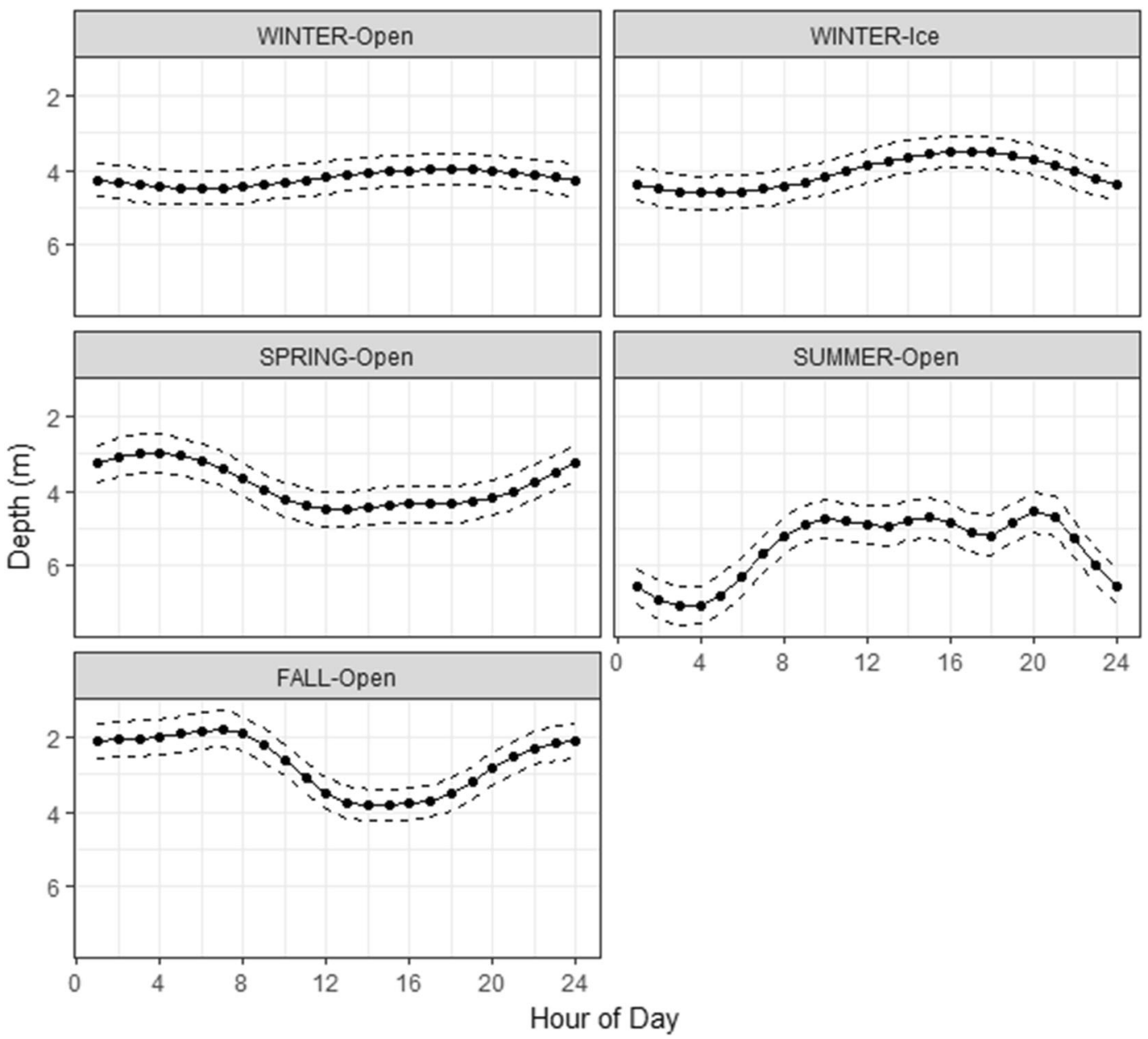

Fig. 7 Predicted depths (with 95\% confidence intervals) occupied by brook trout from the best model that included hour of day and season with ice cover specified 
Fig. 8 Occupied temperature of brook trout (blue dots) relative to range of available temperatures detected in the water column (orange) in Little Bear Cave Pond, NL (fall 2008 through winter 2009). Trout temperatures outside the available temperature range are assumed to reflect occupation of localized temperature anomalies (e.g., ground water inflows)

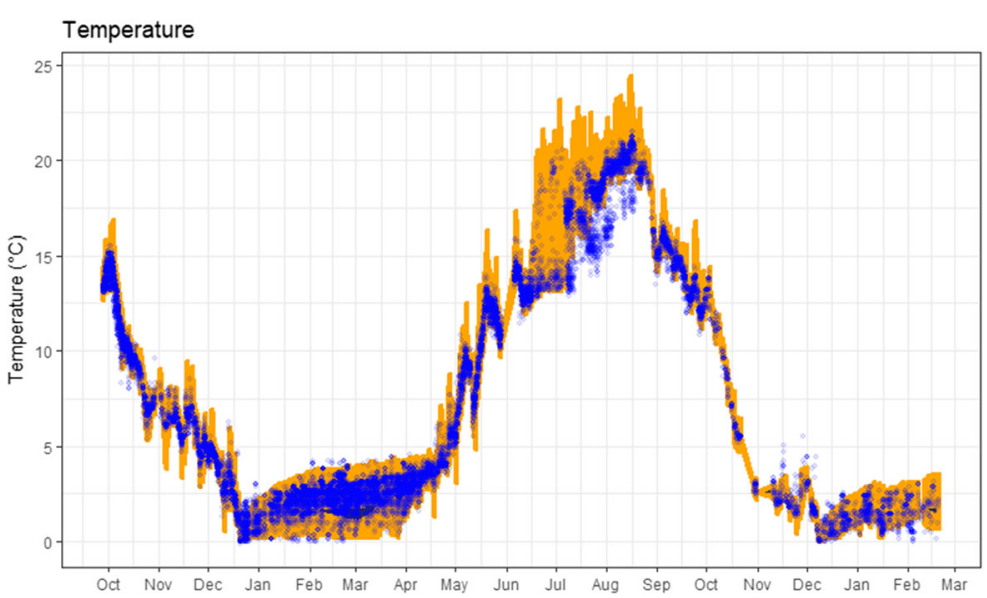

thermoregulation (Curry et al. 1997; Bertolo et al. 2011; Goyer et al. 2014). In the lacustrine habitats of this study, adult brook trout exhibited complex and variable behavior including tendencies of diurnal behavioral patterns and broad habitat use over a wide range of water temperatures, light levels, and ice cover.

Diel patterns of activity and thermoregulation have been described for brook trout in other studies (Bourke et al. 1996; Bertolo et al. 2011) where nocturnal and crepuscular activity patterns and variations within the same waterbody were noted (Bertolo et al. 2011). Brook trout activity patterns observed in this study were diurnal in nature. Elevated diurnal activity is also not uncommon for salmonids (Schulz and Berg 1992; Bjornsson 2001; Baldwin et al. 2002; Bertolo et al. 2011). However, other species of Salvelinus use different strategies in winter. For example, Arctic charr Salvelinus alpinus alter behavior during winter by selecting specific thermal habitats and reducing activity to conserve energy (Mulder et al. 2018b). Lake trout Salvelinus namaycush also change their behavior, moving to pelagic habitats in more spatially restricted, but distinct areas of the lake during the winter period (Blanchfield et al. 2009). Though there was a tendency to occupy deeper areas in summer as observed in lake trout (Blanchfield et al. 2009; Plumb and Blanchfield 2009), brook trout in this study still were found in a wide range of available depths throughout the seasons, despite large changes in temperature. Similarly, diurnal activity patterns were maintained (albeit at reduced rates throughout the winter), even when ice cover greatly reduced light levels in the water column. This too was in opposition to lake trout behavior in winter, which maintained summertime activity levels through winter and were heavily influenced by light (Blanchfield et al. 2009).
Elevated activity rates in brook trout are typically associated with foraging (Boisclair 1992), which suggests that brook trout were primarily feeding during the day in LBCP, as previously observed under laboratory conditions (Hoar 1942). However, the continued movement during dark periods observed in this study shows that movement-related behavior occurs despite low light conditions created by night or ice. Although this might be unexpected in a visual feeder (Sweka and Hartman 2001), brook trout can have varied diets (Cavalli et al. 1997; Cote et al. 2005; Spares et al. 2014), are quite capable of locating food in the dark, and will feed during the day when light is removed (Hoar 1942). Therefore, persistent but slower movements at night or under ice might reflect a shift to a non-visual feeding mode. For example, in a high-altitude lake, Cavalli et al. (1997) observed brook trout diet to shift toward bivalves under ice from a more varied plankton and benthic diet in other seasons. Unfortunately, diet information was not available to provide insight into what activities nighttime movements represented in our study area.

Different diel patterns in depth use were observed across seasons, with shallower nocturnal distributions in spring and fall and deeper nocturnal distributions in winter and summer. In summer, when surface waters were warmer and the water column was strongly stratified, tagged individuals tended to spend the reduced activity period in habitats closer to their thermal optima. In some instances, fish were located in cooler water temperatures than detected by our string of temperature loggers (see Fig. 8) suggesting their use of groundwater flows. Similar summer thermoregulation has been 
observed in lentic brook trout (Bertolo et al. 2011; Goyer et al. 2014) and is thought to enable brook trout access to preferred foraging areas while remaining in close proximity to metabolically favorable, non-feeding habitats (Baird and Krueger 2003; Mucha and Mackereth 2008). If brook trout continue feeding at night on less energetically demanding prey, e.g., sessile organisms, shifting nocturnal depth zones across seasons would also allow brook trout to access prey that may not be available to them during warm, summer periods.

Water temperature was the single most important driver of brook trout activity in LBCP. Water temperature and brook trout activity patterns have been linked in both stream and lake studies (De Staso and Rahel 1994; Bertolo et al. 2011; Goyer et al. 2014) as well as in both laboratory (Tang et al. 2001)- and field-based (Boisclair and Sirois 1993, Marchand et al. 2003) experiments. In LBCP, the range of movement velocity and daily range was limited at low water temperatures, but remained sufficient for brook trout to maintain high and low activity periods during day and night, respectively. It appears, therefore, that feeding continues through the winter which is an inference supported by anglers, who routinely captured brook trout through the ice in LBCP and in many other lakes (Curry et al. 2003). Brook trout have also been observed with full stomachs under the ice in estuarine environments, even though their ability to digest prey items was greatly limited (Spares et al. 2014). Other species of Salvelinus use specific temperature ranges $\left(0.5-2{ }^{\circ} \mathrm{C}\right)$ in winter presumably to conserve energy during reduced feeding periods (Mulder et al. 2018b). For brook trout in LBCP, much of the winter was spent at temperatures near $2-3{ }^{\circ} \mathrm{C}$ even though colder water was available. The occupation of these waters coincided with their low point in active behavior. When they did venture into colder water, it was associated with elevated activity rates and possibly foraging, as sea run brook trout have been observed to use cold and saline waters at $0-2{ }^{\circ} \mathrm{C}$ while improving body condition (Spares et al. 2014).

Diel patterns in activity levels manifested different observed movement velocity responses to water temperature. During active daytime periods, movement velocity increased with temperature in a linear pattern, much like those found in brook trout metabolic models (Hartman and Cox 2008). In contrast, the relationship with temperature and movement velocity was non-linear during low activity nighttime periods. Many studies document physiological responses of brook trout to high water temperatures. For example, activity (Beamish 1964) and energy conversion begin to decline in brook trout at about $17^{\circ} \mathrm{C}$ (McMahon et al. 2007) and Robinson et al. (2010) noted steady declines in consumption by wild brook trout in a non-stratified lake as temperatures increased from 10 to $24^{\circ} \mathrm{C}$. While temperatures in surface waters of LBCP reached as high as $25^{\circ} \mathrm{C}$, the temperatures occupied by brook trout in this study $(<20$ ${ }^{\circ} \mathrm{C}$ ) are thought to be within brook trout's thermal optima (Scott and Crossman 1973; Power 2002). Furthermore, negative effects in other studies were only detected at temperatures beyond the range experienced by fish in this study. For example, Goyer et al. (2014) observed decreased daily movement at temperatures beyond 22.4 ${ }^{\circ} \mathrm{C}$, while Biro (1998) observed lake dwelling young of the year brook trout transition from feeding during the day to defending cool-water refugia when temperatures exceeded $23{ }^{\circ} \mathrm{C}$. Signs of population stress in brook trout have also been documented at temperatures exceeding $20^{\circ} \mathrm{C}$ (Robinson et al. 2010).

The non-linear pattern of velocity-temperature relationships during the lower activity nighttime period was interesting. As water temperature increased from near 0 ${ }^{\circ} \mathrm{C}$, movement velocity dropped sharply until it reached a low at approximately $3{ }^{\circ} \mathrm{C}$. We can only speculate that the high movement velocities at temperatures below 3 ${ }^{\circ} \mathrm{C}$ were not suitable for refuge habitat and thus, occupation of such temperatures were associated with transitory movements. Beyond that, movement velocity only increased very slowly until about $12{ }^{\circ} \mathrm{C}$, after which it tracked a slope similar to daytime velocities. The minimal increase in nocturnal activity across the intermediate temperature range could be an indication that the foraging strategy employed by trout under nonvisual conditions is insensitive to temperature. Other fish species (e.g., Atlantic cod; Cote et al. 2002) have also been observed maintaining swimming speeds across a wide range of temperatures that were presumed to increase metabolic costs (Krohn et al. 1997).

Brook trout in this study clearly incorporated a variety of habitats, taking advantage of ephemeral resources available in mesohabitats within (e.g., lake inflows) and beyond (e.g., spawning grounds) the lake. All tagged brook trout in LBCP moved to the mouth of the inflow in early April where the lake first warmed and lost ice cover. A high rain event on April 4 to 5, followed by a spike in average daily air temperatures from April 8 to 15 , and numerous spikes in water temperature coincided 
with this shift. Similar spring movements to local temperature anomalies have been reported elsewhere for brook trout in streams and rivers (Johnson and Dropkin 1996; Johnson 2008) and in lakes (Erkinaro and Gibson 1997; Biro 1998; Mucha and Mackereth 2008). Migrations occurred at different times between the two years of study and likely corresponded to different flow regimes. We believe, these synchronized movements required awareness of environmental cues, which may have been generated by frequent visits to key habitats. Brook trout have been shown to use extensive areas of lacustrine environments and adjust habitat use in order to find advantageous ecological conditions (Mucha and Mackereth 2008). This simply underscores that there are other benefits to maintaining activity beyond feeding.

Continued activity under low light conditions, during periods of ice cover, as well as a tendency to remain sluggish for a period after dawn is suggestive that light conditions are not a primary driver in brook trout activity. Similar behavior has been observed in brook trout under laboratory settings, where trout tended to feed during the day, even when light was removed (Hoar 1942). The retention of a circadian rhythm in the absence of light has been documented in fish. Cave fish, for example, have been shown to exhibit a circadian rhythm in total darkness and at a constant water temperature (Pradhan 1994). Similarly, Arctic charr maintain seasonal cycles of food consumption irrespective of photoperiod and temperature (Sæther et al. 1996; Tveiten et al. 1996). On the other hand, numerous fishes have been observed to adjust their circadian patterns in response to food availability under constant light conditions, including goldfish (Carassius auratus), mummichog (Fundulus heteroclitus), and both silver (Hypohthalmichtys molitrix) and common (Cyprinus carpio) carp (Spieler 1992). We cannot say with certainty that this rhythm is endogenous or whether brook trout in LBCP were moving in response to external stimuli other than light, such as food availability.

The delay in resumption of diurnal feeding to a few hours after dawn remains perplexing, even though such behavior has also been observed in the laboratory (Hoar 1942). Hoar (1942) observed that fish under controlled conditions, "gradually resumed feeding activity after a night of quiet." In our field study, continued nocturnal activity by brook trout show they do not experience a night of quiet and may very well continue with some feeding. If brook trout are feeding on easily captured benthos in dark conditions (e.g., Cavalli et al. 1997), then it may take them some time to shift modes to mobile prey once light levels increase. Conversely, other salmonids exposed to unpredictable shifts in food availability have shown the ability to quickly change focus from diminished prey species to those that are more available, by using alternate feeding modes (Fausch et al. 1997). It is possible that potential prey sources such as insects follow other environmental variables (e.g., air temperature) that lag behind diel light cycles. We can only speculate that the observed behavior follows the diel patterns of food availability (Spieler 1992).

Brook trout are a littoral zone species (Flick 1991; Magnan and Fitzgerald 1982), associating with the bottom (Tremblay and Magnan 1991) and occupying shallow water $(<7 \mathrm{~m}$ depth) near shore (within $400 \mathrm{~m}$ ) even in cases where much deeper water is available (e.g., Mucha and Mackereth 2008). These tendencies were also apparent in this study, as individuals spent the majority of time in the upper $5 \mathrm{~m}$ of the lake, in close association with the bottom and within $300 \mathrm{~m}$ of shore. It is not surprising, therefore, that the amounts of littoral and shoreline habitats are good predictors of brook trout biomass (Cote et al. 2011). During summer, however, deeper, cooler waters were regularly used and the brook trout's close association to the bottom was diminished. Similar cool-water refuge seeking has been observed for lacustrine young of the year individuals (Biro 1998) and other related species such as lake trout (Guzzo et al. 2017). While deeper water refuges may be less important for feeding and growth, they may become increasingly prominent in explaining brook trout distributions under warming climate scenarios (Robinson et al. 2010). Even with access to deep water refuges, increased reliance on them may have negative consequences to growth and condition as fish are restricted from better foraging habitats (Guzzo et al. 2017).

Ecological rhythms and phenology are an important aspect of a species ecology' since they have evolved to provide animals with adaptations to deal with temporally variable environments (i.e., variable feeding opportunities and/or mortality risk; Hrabik et al. 2006; Armstrong et al. 2016). Changing climate has the potential to extend occupation of refuge habitats of poor foraging quality, which in turn may result in negative energy balance (e.g., Robinson et al. 2010; Guzzo et al. 2017). More research needs to be done to establish the consequences of these habitat shifts for brook trout. 
Acknowledgments The authors extend thanks to Winston Norris (IBEC), Curtis Pennell (DFO), and Donald Keefe (GNL) for field support and technical advice, and Christina Pretty (DFO) for GIS support over the course of the project. We also thank the reviewers and managing editor for very helpful suggestions to the manuscript.

Funding information Financial support for this project was provided by Parks Canada, Fisheries and Oceans Canada, the Government of Newfoundland and Labrador and the Indian Bay Ecosystem Corporation.

Compliance with ethical standards Animal care was done in accordance with the University of New Brunswick's animal care protocols.

Open Access This article is distributed under the terms of the Creative Commons Attribution 4.0 International License (http:// creativecommons.org/licenses/by/4.0/), which permits unrestricted use, distribution, and reproduction in any medium, provided you give appropriate credit to the original author(s) and the source, provide a link to the Creative Commons license, and indicate if changes were made.

\section{References}

Adams BK, Hutchings JA (2003) Microgeographic population structure of brook charr: a comparison of microsatellite and mark-recapture data. J Fish Biol 62:517-533

Anderson WG, McKinley RS, Colavecchia M (1997) The use of clove oil as an anesthetic for rainbow trout and its effects on swimming performance. N Am J Fish Manag 17:301-307

Angilletta MJ Jr, Niewiarowski PH, Navasc CA (2002) The evolution of thermal physiology in ectotherms. J Therm Biol 27: 249-268

Armstrong JB, Takimoto G, Schindler DE, Hayes MM, Kauffman MJ (2016) Resource waves: phenological diversity enhances foraging opportunities for mobile consumers. Ecology 97: $1099-1112$

Baird OE, Krueger CC (2003) Behavioral thermoregulation of brook and rainbow trout: comparison of summer habitat use in an Adirondack river, New York. Trans Am Fish Soc 132: 1194-1206

Baldwin CM, Beauchamp DA, Gubala CP (2002) Seasonal and diel distribution and movement of cutthroat trout from ultrasonic telemetry. Trans Am Fish Soc 131:143-158

Beamish FWH (1964) Respiration of fishes with special emphasis on standard oxygen consumption. Can J Zool 42:177-188

Bertolo A, Pépino M, Adams J, Magnan P (2011) Behavioural thermoregulation tactics in lacustrine brook charr, Salvelinus fontinalis. PLoS One 6:e18603

Biro PA (1998) Staying cool: behavioral thermoregulation during summer by young-of-year brook trout in a lake. Trans Am Fish Soc 127:212-222

Bjornsson B (2001) Diel changes in the feeding behaviour of Arctic char (Salvelinus alpinus) and brown trout (Salmo trutta) in Ellidavatn, a small lake in southwest Iceland. Limnologica 31:281-288
Blanchfield PJ, Tate LS, Plumb JM, Acolas M-L, Beaty KG (2009) Seasonal habitat selection by lake trout (Salvelinus namaycush) in a small Canadian shield lake: constraints imposed by winter conditions. Aquat Ecol 43:777-787

Boisclair D (1992) Relationship between feeding and activity rates for actively foraging juvenile brook trout (Salvelinus fontinalis ). Can J Fish Aquat Sci 49:2566-2573

Boisclair D, Sirois P (1993) Testing assumptions of fish bioenergetics models by direct estimation of growth, consumption, and activity rates. Trans Am Fish Soc 122:784-796

Börger L, Franconi N, De Michele G, Gantz A, Meschi F, Manicam A (2006) Effects of sampling regime on the mean and variance of home range size estimates. J Anim Ecol 75: 1393-1405

Borgstrøm R, Museth J (2005) Accumulated snow and summer temperature - critical factors for recruitment to high mountain populations of brown trout (Salmo trutta L.). Ecol Freshw Fish 14:375-384

Bourke P, Magnan P, Rodriguez MA (1996) Individual variations in habitat use and morphology in brook charr. J Fish Biol 51: 783-794

Brown RS, Hubert WA, Daly SF (2011) A primer on winter, ice and fish: what fisheries biologists should know about winter ice processes and stream-dwelling fish. Fisheries 36:8-26

Burnham KP, Anderson DR (2004) Multimodel inference. Understanding AIC and BIC in model selection. Sociol Methods Res 33:261-304

Calenge C (2006) The package "adehabitat" for the R software: a tool for the analysis of space and habitat use by animals. Ecol Model 197:516-519

Cavalli L, Chappaz R, Bouchard P, Brun G (1997) Food availability and growth of the brook trout, Salvelinus fontinalis (Mitchill), in a French Alpine lake. Fish Manag Ecol 4: 167-177

Chu C, Mandrak NE, Minns CK (2005) Potential impacts of climate change on the distributions of several common and rare freshwater fishes in Canada. Divers Distr 11:299-310

Cote D, Ollerhead LMN, Gregory RS, Scruton DA, McKinley RS (2002) Activity patterns of juvenile Atlantic cod (Gadus morhua) in Buckley Cove, Newfoundland. Hydrobiologia 483:121-127

Cote D, Cox R, Langdon M, Sparkes G (2005) A compilation of fisheries research in ponds of Terra Nova National Park 1997-2003. Parks Canada Tech Rep Ecosyst Sci 46116 pp

Cote D, Adams BK, Clarke KD, Langdon M (2011) Salmonid biomass and habitat relationships for small lakes. Environ Biol Fish 92:351-360

Curry RA, Brady C, Noakes DL, Danzmann RG (1997) Use of small streams by young brook trout spawned in a lake. Trans Am Fish Soc 126:77-83

Curry RA, Brady C, Morgan GE (2003) Effects of recreational fishing on the population dynamics of lake-dwelling brook trout. N Am J Fish Manag 23:35-47

Curry RA, Currie SL, Arndt SK, Bielak AT (2005) Winter survival of age-0 smallmouth bass, Micropterus dolomieu, in north eastern lakes. Environ Biol Fish 72:111-122

Curry RA, van de Sande J, Whoriskey FG (2006) Temporal and spatial habitats of anadromous brook charr in the Laval River and its estuary. Environ Biol Fish 76:361-370

De Staso J, Rahel FJ (1994) Influence of water temperature on interactions between juvenile Colorado River cutthroat trout 
and brook trout in a laboratory stream. Trans Am Fish Soc 123:289-297

Dillon PJ, Clark BJ, Molot L, Evans HE (2003) Predicting end-ofsummer oxygen profiles in stratified lakes. Can J Fish Aquat Sci 60:959-970

Dray S, Royer-Carenzi M, Calenge C (2010) The exploratory analysis of autocorrelation in animal-movement studies. Ecol Res 25:673-681

Erkinaro J, Gibson RJ (1997) Movements of Atlantic salmon, Salmo salar L., parr and brook trout, Salvelinus fontinalis (Mitchill), in lakes, and their impact on single-census population estimation. Fish Manag Ecol 4:369-384

Espinoza M, Farrugia TJ, Webber DM, Smith F, Lowe CG (2011) Testing a new acoustic telemetry technique to quantify longterm, fine-scale movements of aquatic animals. Fish Res 108: 364-371

Fausch KD, Nakano S, Kitano S (1997) Experimentally induced foraging mode shift by sympatric charrs in a Japanese mountain stream. Behav Ecol 8:414-420

Flick WA (1991) Brook trout (Salvelinus fontinalis). In: Stolz J, Schnell J (eds) Trout. Stackpole Books

Fraser DJ, Bernatchez L (2008) Ecology, evolution, and conservation of lake-migratory brook trout: a perspective from pristine populations. Trans Am Fish Soc 137:1192-1202

Goddard SV, Kao MH, Fletcher GL (1992) Antifreeze production, freeze resistance, and overwintering of juvenile Altantic cod (Gadus morhua). Can J Fish Aquat Sci 49:516-522

Goyer K, Bertolo A, Pépino M, Magnan P (2014) Effects of lake warming on behavioural thermoregulatory tactics in a coldwater stenothermic fish. PLoS One 9:e92514

Guy CS, Blankenship HL, Nielsen LA (1996) Tagging and marking. In: Murphy BR, Willis DW (eds) Fisheries Techniques, 2nd edn. American Fisheries Society, Bethesda, pp 353-383

Guzzo MG, Blanchfield PJ (2017) Climate change alters the quantity and phenology of habitat for lake trout (Salvelinus namaycush) in small Boreal Shield lakes. Can J Fish Aquat Sci 77:871-884

Guzzo MG, Blanchfield PJ, Rennie MD (2017) Behavioral responses to annual temperature variation alter the dominant energy pathway, growth, and condition of a cold-water predator. Proc Natl Acad Sci 114:9912-9917

Hartman KJ, Cox MK (2008) Refinement and testing of a brook trout bioenergetics model. Trans Am Fish Soc 137:357-363

Hoar WW (1942) Diurnal variations in feeding activity of young salmon and trout. J Fish Res Bd Can 6:90-101

Hrabik TR, Jensen OP, Martell SJD, Walters CJ, Kitchell JF (2006) Diel vertical migration in the Lake Superior pelagic community. I. Changes in vertical migration of coregonids in response to varying predation risk. Can J Fish Aquat Sci 63: 2286-2295

Huusko A, Greenberg L, Stickler M, Linnansaari T, Nykänen M, Vehanen T, Koljonen S, Louhi P, Alfredsen K (2007) Life in the ice lane: the winter ecology of stream salmonids. River Res Appl 23:469-491

Jardine TD, Cartwright DF, Dietrich JF, Cunjak RA (2005) Resource use by salmonids in riverine, lacustrine and marine environments: evidence from stable isotope analysis. Environ Biol Fish 73:309-319

Jeppesen E, Meerhoff M, Holmgren K, Gonzalez-Bergonzoni I, Teixeira-de Mello F, Declerck SAJ, De Meester L, Søndergaard M, Lauridsen TL, Bjerring R, Conde-Porcuna
JM, Mazzeo N, Iglesias C, Reizenstein M, Malmquist HJ, Zhengwen L, Balayla D, Lazzaro X (2010) Impacts of climate warming on lake fish community structure and potential effects on ecosystem function. Hydrobiologia 646:73-90

Johnson JH (2008) Seasonal habitat use of brook trout and juvenile Atlantic salmon in a tributary of Lake Ontario. Northeast Nat 15:363-374

Johnson J, Dropkin D (1996) Seasonal habitat use by brook trout, Salvelinus fontinalis (Mitchill), in a second-order stream. Fish Manag Ecol 3:1-11

Krohn M, Reidy S, Kerr S (1997) Bioenergetic analysis of the effects of temperature and prey availability on growth and condition of northern cod (Gadus morhua). Can J Fish Aquat Sci 54(Suppl. 1):113-121

Lackey RT (1969) Food interrelationships of salmon, trout, alewives, and smelt in a Maine lake. Trans Am Fish Soc 98: 641-646

Lackey RT (1970) Seasonal depth distribution of landlocked salmon, brook trout, landlocked alewives and American smelt in a small lake. J Fish Res Bd Can 27:1656-1661

Linnansaari T, Cunjak RA (2010) Patterns in apparent survival of Atlantic salmon (Salmo salar) parr in relation to variable ice conditions throughout winter. Can J Fish Aquat Sci 67:1744 1754

Linnansaari T, Cunjak RA (2013) Effects of ice on behaviour of juvenile Atlantic salmon (Salmo salar). Can J Fish Aquat Sci 70:1488-1497

Magnan P, Fitzgerald GJ (1982) Resource partitioning between brook trout (Salvelinus fontinalis Mitchill) and creek chub (Semotilus atromaculatus Mitchill) in selected oligotrophic lakes of southern Quebec. Can J Zool 60:1612-1617

Marchand F, Magnan P, Boischlair D (2003) Differential time budgets of two forms of juvenile brook charr in the openwater zone. J Fish Biol 63:687-698

McClintock B, Michelot T (2018) momentuHMM: R package for analysis of telemetry data using generalized multivariate hidden Markov models of animal movement. https://cran.rproject.org/web/packages / momentuHMM/ vignettes/momentuHMM.pdf

McMahon TE, Zale AV, Barrows FT, Selong JH, Danehy RJ (2007) Temperature and competition between bull trout and brook trout: a test of the elevation refuge hypothesis. Trans Am Fish Soc 136:1313-1326

McMeans BC, McCann KS, Humpphries M, Rooney N, Fisk AT (2015) Food web structure in temporally-forced ecosystems. Trends Ecol Evol 31:662-666

Meyer KA, Gregory JS (2000) Evidence of concealment behavior by adult rainbow trout and brook trout in winter. Ecol Freshw Fish 9:138-144

Mucha JM, Mackereth RW (2008) Habitat use and movement patterns of brook trout in Nipigon Bay, Lake Superior. Trans Am Fish Soc 137:1203-1212

Mulder IM, Morris CJ, Dempson JB, Fleming IA, Power M (2018a) Winter movement activity patterns of anadromous Arctic charr in two Labrador lakes. Ecol Freshw Fish 27:785-797

Mulder IM, Morris CJ, Dempson JB, Fleming IA, Power M (2018b) Overwinter thermal habitat use in lakes by anadromous Arctic char. Can J Fish Aquat Sci 75:2343-2353

Murchie KJ, Smokorowski KE (2004) Relative activity of brook trout and walleyes in response to flow in a regulated river. $\mathrm{N}$ Am J Fish Manag 24:1050-1057 
National Research Council of Canada (2009) http://app.hia-iha. nrc-cnrc.gc.ca/cgi-bin/sun-soleil.pl

Pépino M, Goyer K, Magnan P (2015) Heat transfer in fish: are short excursions between habitats thermoregulatory behavior to exploit resources in an unfavourable thermal environment? J Exp Biol 218:3461-3467

Pépino M, Rodríguez MA, Magnan P (2017) Incorporating lakes in stream fish habitat models: are we missing a key landscape attribute? Can J Fish Aquat Sci 74:629-635

Plumb JM, Blanchfield PJ (2009) Performance of temperature and dissolved oxygen criteria to predict habitat use by lake trout (Salvelinus namaycush). Can J Fish Aquat Sci 66:2011-2023

Power G (2002) Charrs, glaciations and seasonal ice. Environ Biol Fish 64:17-35

Pradhan RK (1994) The influence of photoperiods on the airgulping behaviour of the cave fish Nemacheilus evezardi (Day). Proc Natl Acad Sci India Sect B Biol Sci Allahabad 64:373-380

Prestrud P (1991) Adaptations by the Arctic fox (Alopex lagopus) to the polar winter. Arctic 44:132-138

Robinson JM, Josephson DC, Weidel BC, Kraft CE (2010) Influence of variable interannual summer water temperatures on brook trout growth, consumption, reproduction, and mortality in an unstratified Adirondack lake. Trans Am Fish Soc 139:685-699

Roy R, Beguin J, Argillier C, Tissot L, Smith F, Smedbol S, de Oliviera E (2014) Testing the VEMCO Positioning System: spatial distribution of the probability of location and the positioning error in a reservoir. Anim Biotelemetry 2 https:/animalbiotelemetry.biomedcentral.com/articles/10.1186 /2050-3385-2-1

Sæther B-S, Johnsen HK, Jobling M (1996) Seasonal changes in food consumption and growth of Arctic charr exposed to either simulated natural or a 12:12 LD photoperiod at constant water temperatures. J Fish Biol 48:1113-1122

Schulz U, Berg R (1992) Movements of ultrasonically tagged brown trout (Sulmo trutta L.) in Lake Constance. J Fish Biol 40:909-917

Scott WB, Crossman EJ (1973) Freshwater fishes of Canada. Fisheries Research Board of Canada, Ottawa
Snucins EJ, Gunn JM (1995) Coping with a warm environment: behavioral thermoregulation by lake trout. Trans Am Fish Soc 124:118-123

Spares AD, Dadswell MJ, MacMillan J, Madden R, O'Dor RK, Stokesbury MJW (2014) To fast or feed: an alternative life history for anadromous brook trout Salvelinus fontinalis overwintering within a harbour. J Fish Biol 85:621-644

Spieler RE (1992) Rhythms in Fishes. In: Ali MA (ed) NATO ASI Series, vol 236. Plenum Press, New York, pp 137-147

Spoor WA (1990) Distribution of fingerling brook trout, Salvelinus fontinalis (Mitchill), in dissolved oxygen concentration gradients. J Fish Biol 36:363-373

Sweka JA, Hartman KJ (2001) Fall and winter brook trout prey selection and daily ration. Proc Ann Conf Southeast Assoc Fish Wildl Agenc 55:8-22

Sweka JA, Cox MK, Hartman KJ (2004) Gastric evacuation rates of brook trout. Trans Am Fish Soc 133:204-210

Tang M, Boisclair D, Monard C, Downing JA (2001) Influence of body weight, swimming characteristics, and water temperature on the cost of swimming in brook trout (Salvelinus fontinalis). Can J Fish Aquat Sci 57:1482-1488

Tremblay S, Magnan P (1991) Interactions between two distantly related species, brook trout (Salvelinus fontinalis) and white sucker (Catostomus commersoni). Can J Fish Aquat Sci 48: 857-867

Tveiten H, Johnsen HK, Jobling M (1996) Influence of maturity status on the annual cycles of feeding and growth in Arctic charr reared at constant temperature. J Fish Biol 48:910-924

Utz RM, Hartman KJ (2006) Temporal and spatial variation in the energy intake of a brook trout (Salvelinus fontinalis) population in an Appalachian watershed. Can J Fish Aquat Sci 63: 2675-2686

VEMCO (2008) VR2W Positioning System (VPS) user manual. Report no. DOC-004723-02

Wetzel RG (2001) Limnology: lake and river ecosystems. Academic Press, San Diego

Publisher's note Springer Nature remains neutral with regard to jurisdictional claims in published maps and institutional affiliations. 